\title{
Oxidation of ethane to ethylene and acetic acid by MoVNbO catalysts
}

\author{
M. Roussel ${ }^{1}$, M. Bouchard ${ }^{1}$, E. Bordes-Richard ${ }^{1}$, K. Karim ${ }^{2}$, S. Al-Sayari ${ }^{2}$ \\ ': Laboratoire de Catalyse de Lille, UMR CNRS 8010, USTL-ENSCL, 59655 Villeneuve d'Ascq Cedex, \\ France \\ 2: SABIC R\&T, P.O. Box 42503, Riyadh, Saoudi Arabia
}

\begin{abstract}
The influence of niobium on the physicochemical properties of the Mo-V-O system and on its catalytic properties in the oxidation of ethane to ethylene and acetic acid is examined. Solids based on $\mathrm{MoV}_{0.4} \mathrm{O}_{\mathrm{x}}$ and $\mathrm{MoV}_{0.4} \mathrm{Nb}_{0.12} \mathrm{O}_{\mathrm{y}}$ composition and calcined at 350 or $400^{\circ} \mathrm{C}$ were studied by X-ray diffraction, and by laser Raman and X-ray photoelectron spectroscopies. Their reactivity during reduction and reoxidation was examined by in situ XRD and by XPS after pre-treatment. Their stability in air was evaluated by means of Raman spectroscopy during laser heating of particles. Niobium is responsible for both stabilization and nanosize of $\mathrm{MoO}_{3}$ and $(\mathrm{VNbMo})_{5} \mathrm{O}_{14}$ crystals. The high global selectivity to ethylene and acetic acid (90-96 mol\%) is related to the presence of both phases while higher activity is owed to nanoparticles. The model already proposed by Merzouki et al. (Stud. Surf. Sci. Catal., 72 (1992) 81) suggesting that MoVNbO catalysts could be made up from $(\mathrm{VNbMo})_{5} \mathrm{O}_{14}$-type microdomains embedded in $\mathrm{MoO}_{3}$ matrix seems still topical.
\end{abstract}

\section{Keywords}

$\mathrm{MoVNbO}$ catalysts; acetic acid; ethylene; mild oxidation of ethane; nanosized ( $\mathrm{VNbMo})_{5} \mathrm{O}_{14}$

\footnotetext{
* Corresponding author: Tel: +33(0)3204345 26

Fax: +33 (0)320436561

Mail: Elisabeth.Bordes@univ-lille1.fr
} 


\section{Introduction}

The selective oxidation of n-butane to maleic anhydride has now been successfully processed, and the ammoxidation of propane is very close from industrialization. Although considerable progress has been made, the mastery of mild oxidation of paraffins to valuable chemicals remains difficult for other alkanes $[1,2]$. As it comes out from literature, vanadium- or molybdenum-based catalysts, which are already known for selective oxidation of unsaturated hydrocarbons, are the most useful catalysts for these tasks [3, 4]. Since a long time, their combination resulting in the Mo-V-O system is known to provide good catalysts in several reactions. Among the oldest reactions, benzene oxidation to maleic anhydride [5] proceeds on a solid solution of molybdenum in $\mathrm{V}_{2} \mathrm{O}_{5}\left(\mathrm{~V}_{1.23} \mathrm{Mo}_{0.66} \mathrm{O}_{5}\right)$, and acrolein oxidation to acrylic acid [6, 7] is carried out with phases close to $\mathrm{V}_{2} \mathrm{MoO}_{8}$ [8] $\left(\mathrm{V}_{9} \mathrm{Mo}_{6} \mathrm{O}_{40}\right)$ or to $\mathrm{Mo}_{4} \mathrm{O}_{11}\left(\mathrm{Mo}_{3} \mathrm{VO}_{11}\right)$ [7] structure or stoichiometry. A new application was proposed in the late seventies when Thorsteinson et al. [9] studied the oxidative dehydrogenation of ethane to ethylene. By adding $\mathrm{Nb}$ as a dopant of $\mathrm{MoVO}$ and after a careful study of the phase diagram and of the associated catalytic properties, these authors proposed that the most efficient formula was $\mathrm{Mo}_{0.73} \mathrm{~V}_{0.18} \mathrm{Nb}_{0.9} \mathrm{O}_{\mathrm{y}}$. Acetic acid was formed at high pressure only. Analysis by X-ray diffraction (XRD) showed the patterns of $\mathrm{V}_{9} \mathrm{Mo}_{6} \mathrm{O}_{40}$-type oxides. Solids $\mathrm{Mo}_{6} \mathrm{~V}_{3} \mathrm{Nb}_{1}$ of stoichiometry close to $\mathrm{Mo}_{0.73} \mathrm{~V}_{0.18} \mathrm{Nb}_{0.9} \mathrm{O}_{\mathrm{y}}$ with the same XRD pattern were also studied by Burch and Swarnakar [10]. After various tries to find other catalysts able to form directly acetic acid, Merzouki et al. [11, 12], studied the preparation of $\mathrm{Mo}_{0.73} \mathrm{~V}_{0.18} \mathrm{Nb}_{0.09} \mathrm{O}_{\mathrm{y}}$ catalysts. When $\mathrm{HCl}$ or $\mathrm{H}_{2} \mathrm{C}_{2} \mathrm{O}_{4}$ was added for solubilisation of niobium salt and ammonium vanadate, the solids resulting from heat treatment allowed acetic acid to be obtained at low temperature and atmospheric pressure. Instead of $\mathrm{V}_{9} \mathrm{Mo}_{6} \mathrm{O}_{40}$ (and/or $\mathrm{V}_{6} \mathrm{Mo}_{4} \mathrm{O}_{25}$ ), XRD patterns displayed patterns of orthorhombic $\mathrm{MoO}_{3}$ besides, either $\mathrm{Mo}_{5} \mathrm{O}_{14}$ or $\mathrm{Mo}_{18} \mathrm{O}_{52}$ when the acid added during preparation was $\mathrm{HCl}$ or oxalic acid, respectively. To account for these specific properties, the authors proposed a picture of $\mathrm{MoVNbO}$ catalysts consisting of $\mathrm{Mo}_{5} \mathrm{O}_{14}$-type microdomains (or of $\mathrm{Mo}_{18} \mathrm{O}_{52}$ ) in $\mathrm{MoO}_{3}$ matrix, $\mathrm{V}$ and/or $\mathrm{Nb}$ being possibly included in these suboxides [11]. The properties of this system, including when modified by promotors, have been recently studied for ethane oxidative dehydrogenation [13, 14, 15] but also for production of acetic acid [16-17]. A comprehensive study of $\mathrm{MoV}_{0.25} \mathrm{Nb}_{0.12} \mathrm{Pd}_{0.0005} \mathrm{O}_{\mathrm{y}}$ was led by Linke et al. [18] who suggested that the role of Pd could be to transform ethylene to acetic acid in a Wacker-like process. Promotors like Al, $\mathrm{Fe}, \mathrm{Cr}$, Ti, were proposed by Ueda et al. [19] for the same reaction. Other systems of interest for production of acetic acid and/or ethylene are based on $\mathrm{TiO}_{2^{-}}$[18-22] or $\mathrm{ZrO}_{2}$-supported vanadium oxides [22] or $\mathrm{H}_{4} \mathrm{PMo}_{11} \mathrm{VO}_{40}$ heteropolyacid [22, 23]. 
Catalysts for ammoxidation of propane to acrylonitrile are based on vanadium, like VSbO doped with W or Al [19-26]. Multicomponent catalysts have flourished recently because of the versatility of the MoV system which accommodates several types of dopant, such as catalysts for mild oxidation of propane to acrylic acid [27-32]. If tungsten is generally preferred to $\mathrm{Nb}$ for these reactions, the $\mathrm{Mo}_{5} \mathrm{O}_{14}$-type oxide is often present in the system as detected by XRD and Raman spectroscopy [20,30-34], and as such it may be a key factor to relate to catalytic properties. However, the structure of other phases present in the MoVXYO system and which are related with the presence of dopants X, Y, has been recently solved [35-42] and their presence could make the difference with the MoVNbO system more active for ethane oxidation. Even though a same phase (e.g., $\mathrm{Mo}_{5} \mathrm{O}_{14}$ ) would be present, the action of $\mathrm{W}$ vs. $\mathrm{Nb}, \mathrm{Al}$ vs. Te or $\mathrm{Sb}$, etc., is prominent since their cationic acidity is strongly different $[43,44]$.

In the present paper dedicated to F. Trifiró for his birthday we report on physicochemical properties of catalysts based on $\mathrm{MoV}_{0.4} \mathrm{O}_{\mathrm{x}}$ composition, to which $0.12 \mathrm{Nb}$ has or not been added. To emphasize the role of $\mathrm{Nb}$, their catalytic properties in the oxidation of ethane to acetic acid and ethylene are tentatively related to structural characteristics obtained by X-ray diffraction, laser Raman spectroscopy and X-ray photoelectron spectroscopies, and to reactivity by in situ methods.

\section{Experimental}

Catalysts $\mathrm{MoV}_{0.4} \mathrm{O}_{\mathrm{x}}(\mathrm{MoV})$ and $\mathrm{MoV}_{0.4} \mathrm{Nb}_{0.12} \mathrm{O}_{\mathrm{y}}(\mathrm{MoVNb})$ were prepared according to Karim et al. [15] from ammonium paramolybdate, ammonium metavanadate, and niobium oxalate. After dessication of the mixture, the resulting powder was dried at $120^{\circ} \mathrm{C}$ overnight and then calcined in air up to $\mathrm{Tc}=350^{\circ} \mathrm{C}(\mathrm{MoV} 350, \mathrm{MoVNb} 350)$ or $400^{\circ} \mathrm{C}(\mathrm{MoV} 400, \mathrm{MoVNb} 400)$.

The specific surface area was determined by B.E.T method. XRD patterns were acquired on Huber diffractometer using $\mathrm{CuK} \alpha$ radiation. Lines were assigned to crystalline phases using the DIFFRACPlus software (Bruker) in the range $2 \theta=3-60^{\circ}$. High-temperature X-Ray diffraction was carried out on a Siemens D5000 diffractometer (CuK $\alpha$ radiation), equipped with a HTK 1200 Anton Paar device and a PSD detector. The calibration in temperature of the heating device was checked prior to the experiments using gold powder. Samples were displayed on the sample-holder and heated at $0.06^{\circ} \mathrm{C} / \mathrm{s}$ in $\mathrm{R} / \mathrm{N}_{2}=20 / 80\left(\mathrm{R}=\mathrm{H}_{2}, \mathrm{C}_{3} \mathrm{H}_{8}\right.$ or $\left.\mathrm{C}_{2} \mathrm{H}_{6}\right)$. Patterns were registered at $300,350,400$ and $450^{\circ} \mathrm{C}$ (30 min at each temperature). After cooling down and sweeping by $\mathrm{N}_{2}$, the sample was reoxidised in $\mathrm{O}_{2} / \mathrm{N}_{2}=20 / 80$, and then it returned back to room temperature (R.T.) in the same atmosphere. Raman spectra were recorded using a Labram Infinity laser Raman spectrometer (JYDILOR $®)$. The laser intensity $\left(\mathrm{Ar}^{+}, 514.5 \mathrm{~nm}\right)$ was reduced by various filters $(<1 \mathrm{~mW})$, and the data were treated by Labspec software. The spectral resolution and the accuracy in the Raman shifts are 
estimated to be $\sim 2 \mathrm{~cm}^{-1}$. A tenth particles were examined for each sample to check their homogeneity. The reactivity of samples in air was qualitatively examined by submitting powder grains to the laser beam and decreasing the intensity of filter. The same procedure was used for all samples.

XPS analyses were performed using the ESCALAB 220XL spectrometer. The powder samples were pressed in a $2 \mathrm{~mm}$ hole in a steel block. The AlK $\alpha$ monochromatized line $(1486.6 \mathrm{eV})$ was used at $120 \mathrm{kV}$ giving a $500 \mu \mathrm{m}$ spot diameter in the sample. The spectrometer was operated in a constant pass energy mode $\left(\mathrm{E}_{\text {pass }}=30 \mathrm{eV}\right)$ for the high resolution spectra recording using the electromagnetic lens mode. There was no need of flood gun source as the samples were conducting enough. Binding energies were referenced to $\mathrm{O} 1 \mathrm{~s}$ core $530.20 \mathrm{eV}$ for oxygen. During experiment the vacuum level was less than $10^{-7} \mathrm{~Pa}$. Experimental quantification level and spectral simulation were obtained using the Eclipse software provided by VG Scientific. The area of Mo $\left(3 \mathrm{~d}_{3 / 2}, 3 \mathrm{~d}_{5 / 2}\right), \mathrm{V}\left(2 \mathrm{p}_{3 / 2}\right)$ and $\mathrm{Nb}\left(3 \mathrm{~d}_{3 / 2}\right.$, $3 d_{5 / 2}$ ) peaks was measured for each sample and the surface stoichiometry was determined. Signals were deconvoluted in order to get the amount of oxidized and reduced cations. The surface oxygen stoichiometry was then calculated and compared to the two extremum values obtained from bulk stoichiometry by considering cations in their oxidized or in their reduced forms. In order to observe the effect of reduction and reoxidation on the valence of $\mathrm{Mo}, \mathrm{V}$ or $\mathrm{Nb}$, samples were treated by a reducing mixture $\left(\mathrm{H}_{2} / \mathrm{N}_{2}\right.$, propane $/ \mathrm{N}_{2}$ or ethane $\left./ \mathrm{N}_{2}=0.2\right)$ for $30 \mathrm{~min}$ at $300^{\circ} \mathrm{C}$ in the pre-treatment chamber of the VG-Escalab apparatus, and then introduced (without exposure to air) inside the vacuum chamber for acquisition of XPS spectrum. The pre-treatment temperature of $300^{\circ} \mathrm{C}$ was chosen because $(\mathrm{VNbMo})_{5} \mathrm{O}_{14}$ phases are still visible by High Temperature-XRD. Then the reduced samples were submitted to $\mathrm{O}_{2} / \mathrm{N}_{2}=20 / 80$ flow for $30 \mathrm{~min}$ at $300^{\circ} \mathrm{C}$ in the pre-treatment chamber and examined.

The catalytic properties were measured using a conventional flow set-up, effluents being analyzed by on-line GC. The stainless-steel fixed bed reactor was placed in a tubular furnace and connected to the analysis set up. The inlet gas mixture of propane, oxygen and nitrogen was controlled using mass flowmeters. The reactor (volume of catalyst $=3 \mathrm{~mL}$ ) was fed with $\mathrm{C}_{2} \mathrm{H}_{6} / \mathrm{O}_{2} / \mathrm{N}_{2}=40 / 6 / 54$ and operated at $240-280^{\circ} \mathrm{C}$ and contact time $\tau=1 \mathrm{~s}$. Reactants and products were analysed on-line with a gas chromatograph equipped with a double detector (thermal conductivity and flame ionization) and two columns, HayeSep D 80/100 mesh, and LAC446. In these conditions, the carbon balance was met at $\pm 1 \%$. 


\section{Results}

\section{Physicochemical analyses}

\section{1-1. XRD analysis}

Analyses performed on fresh catalysts, with or without $\mathrm{Nb}$, show distinct differences according to the calcination temperature Tc.

- Nb-free samples: The patterns of MoV350 and MoV400 display lines assigned to several phases (Fig. 1), among which orthorhombic $\alpha-\mathrm{MoO}_{3}$. Its amount and crystallinity is increased when $\mathrm{Tc}=400^{\circ} \mathrm{C}(\mathrm{MoV} 400)$. It must be noted however that there is no $\mathrm{V}_{9} \mathrm{Mo}_{6} \mathrm{O}_{40}$ nor $\mathrm{V}_{2} \mathrm{MoO}_{8}$ which are often characterized $[9,10,13]$ in this type of sample. Most lines of $\alpha-\mathrm{MoO}_{3}$ are shifted to the lowest dspacing $\left(2 \theta \sim-0.02\right.$ to $\left.+0.05^{\circ}\right)$ as compared to the theoretical position of $\alpha-\mathrm{MoO}_{3}$ lines (JCPDS 761003). This shift could be assigned to a modification in the crystallographic structure of $\alpha-\mathrm{MoO}_{3}$ by vanadium or to the formation of oxygen vacancies as in $\mathrm{MoO}_{3-\mathrm{x}}$. The $\mathrm{Mo}_{5} \mathrm{O}_{14}$-type structure (called $\theta$-phase [21]) may be accounted for by its strongest reflections at $d(\AA) / 2 \theta=3.99 / 22.5^{\circ}$ and $3.56 / 24.94^{\circ}$ which are observed in MoV350 while the two medium lines at $11.4 / 7.74^{\circ}$ and $10.2 / 8.67^{\circ}$ are present as a small "band". The incorporation of vanadium as $\left(\mathrm{V}_{0.07} \mathrm{Mo}_{0.93}\right)_{5} \mathrm{O}_{14}$ [21] cannot be checked because too many lines of other phases are present. The $\theta$-phase lines are absent in MoV400. Other phases are $\mathrm{V}_{0.12} \mathrm{Mo}_{0.88} \mathrm{O}_{2.94}$ which is a defective solid solution of $\mathrm{V}$ in the hexagonal form of $\mathrm{MoO}_{3}$ (JCPDS 81-2414), and triclinic $\mathrm{V}_{0.95} \mathrm{Mo}_{0.97} \mathrm{O}_{5}$ (JCPDS 77-0649), the pattern of which is very close from that proposed for $\mathrm{VMo}_{3} \mathrm{O}_{11}[7]$.

- Nb-containing samples: The XRD pattern of MoVNb350 (Fig. 1) is made up from several very broad reflections at $\mathrm{d}(\AA) / 2 \theta \sim 10.8 / 8.1^{\circ} ; 4.00 / 22.1^{\circ} ; 3.28 / 27.1^{\circ} ; 2.59 / 34.5^{\circ} ; 1.99 / 45.38^{\circ}$; $1.86 / 48.75^{\circ}$. This pattern, which is similar to those observed in MoVWO catalysts [27], is characteristic of a mixture of $\mathrm{Mo}_{5} \mathrm{O}_{14}$-type structure and of $\alpha-\mathrm{MoO}_{3}$ nanocrystallites [33-35, 46]. Several authors $[10,33,47]$ identified $\mathrm{NbVO}_{5}$ and $\mathrm{Nb}_{2} \mathrm{Mo}_{3} \mathrm{O}_{11}\left(\right.$ or $3 \mathrm{MoO}_{2} \cdot \mathrm{Nb}_{2} \mathrm{O}_{5}$, JCPDS 18-0840) in $\mathrm{VNbMO}(\mathrm{M}=\mathrm{Mo}, \mathrm{Sb}, \mathrm{Si})$ catalysts for the $\mathrm{ODH}$ of propane. $\mathrm{NbVO}_{5}$ is clearly absent from the pattern of MoVNb350 while $\left(\mathrm{V}_{0.07} \mathrm{Mo}_{0.93}\right)_{5} \mathrm{O}_{14}$ and/or $\left(\mathrm{Nb}_{0.09} \mathrm{Mo}_{0.91}\right) \mathrm{O}_{2.80}$ (JCPDS 27-1310) are present (Fig. 5). The wide massif and the reflection at respectively $(\mathrm{d}(\AA) / 2 \theta) 10.92 / 8.08^{\circ}$ and $4.00 / 22.2^{\circ}$ respectively correspond to the most intense lines of these two compounds. Owing to the low amount of $\mathrm{Nb}$ in $\mathrm{MoV}_{0.4} \mathrm{Nb}_{0.12} \mathrm{O}_{\mathrm{y}}$ formula, it would be surprising to form $\mathrm{Nb}_{2} \mathrm{Mo}_{3} \mathrm{O}_{11}$ (or $3 \mathrm{MoO}_{2} \cdot \mathrm{Nb}_{2} \mathrm{O}_{5}$ ). As this pattern is very close from that of $\left(\mathrm{Nb}_{0.09} \mathrm{Mo}_{0.91}\right) \mathrm{O}_{2.80}$ and because of the amorphous character of the sample, it is not easy to decide which is which. Such phases will be further mentioned as $(\mathrm{MoVNb})_{5} \mathrm{O}_{14}$. After 
being calcined at $400^{\circ} \mathrm{C}$, samples exhibit lines of $\alpha-\mathrm{MoO}_{3}$ superimposed to the preceding pattern, which shows that $\alpha-\mathrm{MoO}_{3}$ nanoparticles already present at lower temperature have partly grown as bigger crystals.

\section{1-2. Laser Raman spectroscopy (LRS)}

The composition of samples on the glass holder is rather homogeneous as the same spectrum is observed, except that intensity of bands can be slightly different. The spectra of MoV and MoVNb (Fig. 2) differ at first glance by the presence of absorption bands of $\alpha-\mathrm{MoO}_{3}$ (bands at 996, 820, 667, 290, $160 \mathrm{~cm}^{-1}$ ) in the former, and which are more conspicuous for MoV400 (Fig. 2). In general, Raman bands at $860-940 \mathrm{~cm}^{-1}$ characterize the M'-O-M stretching mode of polycrystalline metal oxide phase, and bands at 932 and $873 \mathrm{~cm}^{-1}$ are related to $\mathrm{M}-\mathrm{O}-\mathrm{V}$ phases. Bands ca. $1000 \mathrm{~cm}^{-1}$ are assigned to $\mathrm{M}=\mathrm{O}$ stretching mode $\left(996 \mathrm{~cm}^{-1}\right)$. The shoulder close to $700 \mathrm{~cm}^{-1}$ in MoV400 is assigned to $\mathrm{V}-\mathrm{O}-\mathrm{V}$ in $\mathrm{V}_{2} \mathrm{O}_{5}$. A band with a maximum of intensity ca. $875-880 \mathrm{~cm}^{-1}$ with a shoulder ca. $920 \mathrm{~cm}^{-1}$ is present in both $\mathrm{MoV}$ and MoVNb samples. According to Mestl et al. [34, 35, 46], these bands are characteristic of $\mathrm{Mo}_{5} \mathrm{O}_{14}$-type structure. Most XRD findings are thus confirmed by LRS which that, (i), crystalline particles of $\alpha-\mathrm{MoO}_{3}$ grow when Tc increases, (ii), $\mathrm{Nb}$ influences both the formation of $\mathrm{Mo}_{5} \mathrm{O}_{14}$-type phase and the crystallinity of the material (including $\mathrm{MoO}_{3}$ ) which is poorer in its presence.

The reactivity of samples has been qualitatively estimated by using the laser beam to heat the grains on sample holder. The same definite procedure was repeated for all samples. During laser heating of $\mathrm{MoV} 350, \mathrm{MoO}_{3}$ bands at 284, 819 and $990 \mathrm{~cm}^{-1}$ are seen to grow, at the expense of bands characteristic of Mo-O-V stretching mode $\left(\sim 873\right.$ and $\left.\sim 925 \mathrm{~cm}^{-1}\right)$ which decrease and disappear. The same phenomenon is observed with MoV400 (Fig. 2). When $\mathrm{Nb}$ is present, the intensity of $\mathrm{MoO}_{3}$ bands grows only in the case of MoVNb400 and the band structure characteristic of $(\mathrm{MoVNb})_{5} \mathrm{O}_{14}$ remains. The $\theta$-phase is therefore stabilized by the presence of $\mathrm{Nb}$.

\section{1-3. X-ray Photoelectron Spectroscopy (XPS)}

The binding energies (BE) and FWHM of Mo, V, Nb and $\mathrm{O}$ photopeaks are representative of $\mathrm{Mo}^{6+}, \mathrm{V}^{5+}, \mathrm{Nb}^{5+}$ and of $\mathrm{O}^{2-}$ in transition metal oxides (Table 1). The $\mathrm{BE}$ of $\mathrm{Mo}^{6+}$ is $232.4-232.1 \mathrm{eV}$ and its symmetry and FWHM do not allow to say that $\mathrm{Mo}^{4+}$ or $\mathrm{Mo}^{5+}$ are present in samples. On the contrary, the $\mathrm{V} 2 \mathrm{p}_{3 / 2}$ signal is too large to account only for only $\mathrm{V}^{5+}$, and after deconvolution the presence of $\mathrm{V}^{4+}$ is ascertained. The $\mathrm{BE}$ of $\mathrm{Nb}^{2} \mathrm{~d}_{5 / 2}$ is 206.7 in MoVNb350, and slightly lower $\left(206.3 \mathrm{eV}\right.$ ) after calcination at $400^{\circ} \mathrm{C}$. According to whether the oxidation state of $\mathrm{V}$ is +5 or +4 , the bulk stoichiometry of as-prepared MoV lies between $\mathrm{Mo}^{6+} \mathrm{V}^{5+}{ }_{0.4} \mathrm{O}_{4}$ and $\mathrm{Mo}^{6+} \mathrm{V}^{4+}{ }_{0.4} \mathrm{O}_{3.8}$. The V/Mo ratio 
shows that the surface of MoV400 is enriched with Mo. This result is well correlated with the presence of $\mathrm{MoO}_{3}$ detected by XRD and LRS. Although $\mathrm{MoVNb} 400$ is calcined at the same temperature, its surface is closer from stoichiometry. The presence of $\mathrm{Nb}$ modifies the amount of surface $\mathrm{V}^{4+}$. The $\mathrm{V}^{5+} / \mathrm{V}^{4+}$ ratio amounts to ca. 2.7-2.8 and 4.1-5.1 for MoV and MoVNb, respectively, but the amount of $\mathrm{V}^{4+}$ vs. Mo remains nearly constant in the latter.

\section{In situ analyses}

\section{3-1. High Temperature X-Ray Diffraction (HT-XRD)}

Reduction: By heating MoV350 in $\mathrm{H}_{2} / \mathrm{N}_{2}$ (Fig. 3), $\mathrm{MoO}_{2}$ is formed above $350^{\circ} \mathrm{C}$ since its main line $\left(2 \theta=26.0^{\circ}\right)$ begins to be detectable at $400^{\circ} \mathrm{C}$, whereas the line at $22^{\circ}$ as well as those of $\mathrm{MoO}_{3}$ have disappeared at $450^{\circ} \mathrm{C}$. Other lines of $\mathrm{MoO}_{2}\left(2 \theta \sim 26.0,37.0,41.5,53-54^{\circ}\right)$ occur above $400^{\circ} \mathrm{C}$ while no line of $\mathrm{VO}_{2}$ is observed. MoVNb350 is reduced in the same range but, that time, lines characteristic of $\mathrm{V}_{\mathrm{x}} \mathrm{Mo}_{1-\mathrm{x}} \mathrm{O}_{2}(\mathrm{x}=0.33)$ solid solution appear at 37.8 and $54.3^{\circ}$ besides $2 \theta \sim 26.2,36.6$, $41.3,53.4^{\circ}$ (Fig. 5). At $450^{\circ} \mathrm{C}$, the large lines at $2 \theta \sim 22.1,27.5,34.8,45.4^{\circ}$ assigned to $(\mathrm{MoVNb})_{5} \mathrm{O}_{14}$ and $\mathrm{MoO}_{3}$ nanocrystallites have disappeared. It is difficult to know if $\mathrm{Nb}$ is incorporated or not in the $\mathrm{V}_{\mathrm{x}} \mathrm{Mo}_{1-\mathrm{x}} \mathrm{O}_{2}$ solid solution in the absence of an internal standard. However there is no JCPDS file of a solid solution between $\mathrm{V}$ and $\mathrm{Nb}$ or $\mathrm{Nb}$ and $\mathrm{Mo}$.

Reoxidation: The main phases identified in patterns of MoV350 at $450^{\circ} \mathrm{C}$ (Fig. 4) and after cooling are $\alpha-\mathrm{MoO}_{3}$ and $\mathrm{V}_{9} \mathrm{Mo}_{6} \mathrm{O}_{40}$, which means that part of $\mathrm{MoO}_{2}$ recombines with some vanadium oxide to give $\mathrm{V}_{9} \mathrm{Mo}_{6} \mathrm{O}_{40}$ or $\mathrm{V}_{2} \mathrm{MoO}_{8}$. Actually, $\mathrm{V}_{9} \mathrm{Mo}_{6} \mathrm{O}_{40}$ is a solid solution of $\mathrm{V}_{2} \mathrm{MoO}_{8}$-type, and this accounts for small $\mathrm{d}$ shifts and for variable intensity of some lines observed sometimes, when comparing JCPDS patterns [8]. The width of lines indicates that particles are small. After reoxidation of MoVNb350 at $450^{\circ} \mathrm{C}$ (Fig. 6) the main lines of $\alpha-\mathrm{MoO}_{3}$ and $\mathrm{Mo}_{6} \mathrm{~V}_{9} \mathrm{O}_{40} / \mathrm{V}_{2} \mathrm{MoO}_{8}$ appear besides those (wider) at $2 \theta \sim 22,27,45$ and $49^{\circ}$. These lines, which had disappeared from patterns after reduction, are assigned to $(\mathrm{MoVNb})_{5} \mathrm{O}_{14}$ and their smaller width indicates that meanwhile the crystallinity of this phase has increased. Compared with $\mathrm{MoV}$ pattern after reoxidation, the occurrence of several lines assigned to crystallised $(\mathrm{MoVNb})_{5} \mathrm{O}_{14}$ is remarkable and undoubtedly related to the presence of $\mathrm{Nb}$. 


\section{3-2. High Temperature-XPS}

\section{3-2-1. Reduction by hydrogen and reoxidation by air (Table 2 )}

Only the vanadium signal is affected by reduction of samples (Fig. 7) while BEs of $\mathrm{Mo}^{6+}$ and of $\mathrm{Nb}^{5+}$ (when present) remain at 232.25 and $206.7 \mathrm{eV}$, respectively. In $\mathrm{MoV}$ as well as in MoVNb the deconvolution of vanadium signal yields $\mathrm{V}^{5+}$ and $\mathrm{V}^{4+}$ at 517.0 and $516.0 \mathrm{eV}$, respectively (Table 2).gathers atomic ratios and stoechiometries after reduction and after reoxidation. The bulk stoichiometry of MoV lies between $\mathrm{Mo}^{6+} \mathrm{V}^{5+}{ }_{0.4} \mathrm{O}_{4}$ and $\mathrm{Mo}^{6+} \mathrm{V}^{4+}{ }_{0.4} \mathrm{O}_{3.8}$ if only vanadium is reduced. By reoxidation the initial stoichiometry before experiments is not recovered and less $\mathrm{V}^{5+}$ are found on surface, which explains why all vanadium (IV) is not reoxidized. During these experiments, the V/Mo ratio remains remarkably stable but low, which means that the surface is strongly enriched with Mo as compared to bulk. In the case of MoVNb (bulk stoichiometry between $\mathrm{Mo}^{6+} \mathrm{V}^{5+}{ }_{0.4} \mathrm{Nb}^{5+}{ }_{0.125} \mathrm{O}_{4.31}$ and $\mathrm{Mo}^{6+} \mathrm{V}^{4+}{ }_{0.4} \mathrm{Nb}^{5+}{ }_{0.125} \mathrm{O}_{4.11}$ ), V/Mo is slightly greater and decreases by reduction, while $\mathrm{Nb} / \mathrm{Mo}$ increases slightly. When calculating $\mathrm{V}^{4+} / \mathrm{Mo}$, it is seen that the reduction of $\mathrm{MoV}$ is deeper than that of MoVNb. Therefore, the presence of $\mathrm{Nb}$ can be said to decrease the surface reducibility of vanadium and to stabilize molybdenum. The Nb/Mo ratio is close to the 0.125 bulk value, but it increases after reduction and reoxidation. As both $\mathrm{V} / \mathrm{Mo}$ and $\mathrm{Nb} / \mathrm{Mo}$ increases for MoVNb as compared to $\mathrm{MoV}$ catalyst, this could mean that less Mo comes towards the surface in the case of MoVNb.

\section{3-2-2. Reduction by propane or ethane and reoxidation by air (Table 3 )}

Similar reduction patterns are observed during reduction by propane or ethane. There is the same V/Mo ratio and the same stable Mo-rich surface of MoV, and there is less Mo on surface of $\mathrm{MoVNb}$. The reduction of $\mathrm{MoV}$ is slightly deeper than that of MoVNb. Therefore, replacing hydrogen by propane or ethane does not strongly modify the behavior of samples, although in the latter case, less $\mathrm{Nb}$ is present on surface.

\section{Catalytic properties.}

Preliminary catalytic data are presented in Table 4. Catalytic experiments were deliberately performed in conditions of temperature and contact time such that oxygen was not fully converted. In the strongly reducing used conditions $\left(\mathrm{C}_{2} \mathrm{H}_{6} / \mathrm{O}_{2}=40 / 4\right)$, the maximum theoretical yields (referred to ethane at $100 \mathrm{~mol} \%$ selectivity) are $20 \mathrm{~mol} \%$ for ethylene and $6.67 \mathrm{~mol} \%$ for acetic acid, respectively. The main products were ethylene and acetic acid, followed by $\mathrm{CO}$ and $\mathrm{CO}_{2}$, with traces of acetaldehyde and formaldehyde. 
When temperature of reaction $T_{R}$ increases, the conversion of ethane is parallel to that of oxygen and increases while selectivity to partial oxidation products decreases. Ethylene production is systematically higher than that of acetic acid $\left(\mathrm{Y}_{\mathrm{C} 2} / \mathrm{Y}_{\mathrm{AA}}=1.9-2.6\right)$, and carbon oxides are low. The global selectivity to ethylene and acetic acid decreases when $T_{R}$ increases, and amounts to 90-96 mol\% depending on samples. The main exception is MoV400, on which more carbon oxides are produced (selectivity ca. 50-28 mol\%) but it is, however, the least active sample. Conversions are lower when calcination temperature Tc increase, but this effect is more noticeable in Nb-free samples. The maximum yields to ethylene and acetic acid are obtained with MoVNb350 and amount to 8.4 and $4.2 \mathrm{~mol} \%$, respectively. Except with MoV400, the global selectivity as well as the ethylene-to-acetic acid ratio (3.0-3.8/1) does not vary much, which means, in first approximation, that the reaction mechanism is the same and that the main differences rely on the activity of particles.

\section{Discussion}

In early papers dealing with MoVO system for various applications, the presence or not of a strong XRD line ca. $d(\AA) / 2 \theta^{\circ}=4.0 / 22$ has often been taken as an indication of good catalytic properties. Several phases may present such a line in their pattern while others do not, and most of them are gathered in Table 5. In our samples, $\theta-\mathrm{Mo}_{5} \mathrm{O}_{14}$, which belongs to the former group, has been identified, except in MoV400 where most lines belong to orthorhombic $\mathrm{MoO}_{3}$. The absence of $\mathrm{V}_{9} \mathrm{Mo}_{6} \mathrm{O}_{40}$ (or $\mathrm{V}_{2} \mathrm{MoO}_{8}$ ) is noticeable in $\mathrm{MoV}$ and $\mathrm{MoVNb}$ samples while it has been found in earlier $[9,10]$ or more recent [48] works. The presence of the recently found phases, like the orthorhombic M1 and hexagonal M2 (or those closely related to them) [36-42], whose patterns are very close from that of $\theta-\mathrm{Mo}_{5} \mathrm{O}_{14}$, is difficult to ascertain in $\mathrm{MoVNb}$ because of poor crystallinity. Moreover, the broad envelope ca. $2 \theta=10^{\circ}$ may refer to nanocrystallized $\theta-\mathrm{Mo}_{5} \mathrm{O}_{14}$ as well as $\alpha-\mathrm{MoO}_{3}$ (strong line at $2 \theta=$ $\left.9.69^{\circ}\right)$ as demonstrated by Mestl et al. [46]. Therefore, we shall assume that, as confirmed by LRS, $\theta$ $\mathrm{Mo}_{5} \mathrm{O}_{14}$ and $\alpha-\mathrm{MoO}_{3}$ constitute the common base of our catalysts, besides other phases like $\mathrm{V}_{0.12} \mathrm{Mo}_{0.88} \mathrm{O}_{2.94}$ and $\mathrm{V}_{0.95} \mathrm{Mo}_{0.97} \mathrm{O}_{5}$ in $\mathrm{Nb}$-free samples. XRD and LRS show that the crystallinity of materials depends on temperature of calcination $\mathrm{Tc}$, as well as on the presence/absence of $\mathrm{Nb}$. Calcining $\mathrm{MoV}$ and $\mathrm{MoVNb}$ solids at $400^{\circ} \mathrm{C}$ results in the growing of $\mathrm{MoO}_{3}$ crystals, which, however, are far smaller in the presence of $\mathrm{Nb}$. Surface composition as determined by XPS shows that part of vanadium is reduced $\left(\mathrm{V}^{4+}\right)$, and that the surface is as enriched with $\mathrm{Mo}$ as $\mathrm{Tc}=400^{\circ} \mathrm{C}$ and as $\mathrm{Nb}$ is absent.

One of the main questions to answer is the formation of solid solutions in the metastable $\theta$-phase, which is known to be stabilized by several cations to a given extent [45]. The 
maximum solubility is, e.g., 11 at.\% of $\mathrm{V}, 9$ at. $\%$ of $\mathrm{Nb}$ and up to 30 at.\% of $\mathrm{W}$. In $\mathrm{Nb}$-free catalysts, $\theta$ may be stabilized as $\left(\mathrm{V}_{0.07} \mathrm{Mo}_{0.93}\right)_{5} \mathrm{O}_{14}$ but this hypothesis cannot be checked by XRD because of the presence of other oxides. Whereas $\mathrm{V}^{5+}$ is too small a cation, $\mathrm{V}^{4+}$ may accept the 8-coordination and its ionic radius being $0.72 \AA$ [ 49 it may replace Mo in pentagonal bipyramids. The amount of $\mathrm{V}^{4+}$ determined by XPS (Table 1) is convenient, but to fit the oxygen stoichiometry in $\mathrm{V}^{4+}{ }_{0.07} \mathrm{Mo}_{0.93} \mathrm{O}_{2.80}$, $0.26 \mathrm{Mo}$ should be as $\mathrm{Mo}^{5+}$, which is unlikely because of both the high symmetry and FWHM of $\mathrm{Mo}(3 \mathrm{~d})$ photopeak. Recently, an oxide with $\mathrm{V}^{4+} \mathrm{Mo}^{6+}{ }_{4} \mathrm{O}_{14}$ stoichiometry and isostructural with the $\theta$-phase has been synthesized and characterized [30]. Owing to the initial $\mathrm{MoV}_{0.4} \mathrm{O}_{\mathrm{x}}$ stoichiometry this oxide could also be formed, in accordance with the presence of $\mathrm{Mo}^{6+}$. Using $\mathrm{V}^{4+} / \mathrm{V}_{\text {tot }} \approx 25 \%$ close from XPS value, a rough composition of MoV350 could be $0.1 \mathrm{~V}^{4+} \mathrm{Mo}^{6+}{ }_{4} \mathrm{O}_{14}+0.3 \mathrm{~V}_{0.95} \mathrm{Mo}_{0.97} \mathrm{O}_{5}+0.2$ $\mathrm{MoO}_{3}+0.1 \mathrm{~V}_{0.12} \mathrm{Mo}_{0.88} \mathrm{O}_{2.94}$.

Things are different in $\mathrm{Nb}$-containing catalysts. The amorphous character presented by both XRD patterns and LRS spectra of MoVNb samples is owed to the very small size of $\theta-\mathrm{Mo}_{5} \mathrm{O}_{14}$ and $\alpha$ $\mathrm{MoO}_{3}$ crystallites [34]. Generally speaking, the thermodynamic trend exhibited by particles of amorphous materials is to reorganize and to grow in order to reach a more stable state, unless they are stabilized in another manner. Laser heating in LRS provides a means to study the stability in air. It was observed that, while in $\mathrm{MoV}$ samples the bands of $\mathrm{MoO}_{3}$ grow as those of $\theta$-phase disappear, in $\mathrm{Nb}$-containing samples the latter remain. Niobium is undoubtedly responsible for this stabilisation and an explanation is the formation of the solid solution, as $\left(\mathrm{Nb}_{0.09} \mathrm{Mo}_{0.91}\right) \mathrm{O}_{2.80}$. $\mathrm{Nb}^{5+}$ accepts 8-coordination, and thus it may be located in pentagonal columns $\left(\mathrm{r} \mathrm{Nb}^{5+}=0.74 \AA\right.$ ) [45]. Again XRD experiments do not allow to verify the hypothesis, that time because of the amorphous character of $\mathrm{XRD}$ patterns and LRS spectra. However, another, though indirect, proof that $\mathrm{V}$ and/or $\mathrm{Nb}$ could enter the $\theta$-phase lattice is provided by in situ HT-XRD experiments on samples calcined at $350^{\circ} \mathrm{C}$. The reduction of the $\mathrm{Nb}$-free sample by hydrogen shows that $\mathrm{MoO}_{2}$ is formed while no line accounts for the presence of vanadium oxide, and the reoxidation does not give back the $\theta$-phase but $\mathrm{V}_{9} \mathrm{Mo}_{6} \mathrm{O}_{40}$ and $\mathrm{MoO}_{3}$. On the contrary, the same experiments on MoVNb show that, not only the reduction yields the $(\mathrm{MoV}) \mathrm{O}_{2}$ solid solution, but also the reoxidation gives back $(\mathrm{VNbMo})_{5} \mathrm{O}_{14}$ (besides $\mathrm{V}_{9} \mathrm{Mo}_{6} \mathrm{O}_{40}$ and $\alpha$ $\left.\mathrm{MoO}_{3}\right)$. Moreover, meanwhile the crystallinity of $(\mathrm{VNbMo})_{5} \mathrm{O}_{14}$ has increased. If more Mo is stabilized by formation of $(\mathrm{VNbMo})_{5} \mathrm{O}_{14}$, it is normal that XPS shows less 'free' Mo (probably as $\mathrm{MoO}_{3}$ ) on surface than in $\mathrm{MoV}$, and that $\mathrm{Nb}$ tends to be more present among the bulk.

'In situ' XPS experiments also provide informations (Tables 2 and 3). The temperature of pretreatment $\left(300^{\circ} \mathrm{C}\right)$ was chosen in accordance with $\mathrm{T}_{\mathrm{R}}$ of catalytic experiments. No formation of reduced molybdenum $\left(\mathrm{Mo}^{5+}, \mathrm{Mo}^{4+}\right)$ was observed, in accordance with HT-XRD since, at this temperature, no $\mathrm{MoO}_{2}$ was yet formed. The reduction affects vanadium in similar amounts $\left(\mathrm{V}^{4+} / \mathrm{V}_{\text {tot }}=\right.$ 0.59-0.67) whatever the reducing agent, and at first sight less $\mathrm{V}$ is reduced in the presence of $\mathrm{Nb}$ $\left(\mathrm{V}^{4+} / \mathrm{V}_{\text {tot }}=0.59-0.64\right.$ for $\mathrm{MoVNb}$ vs. $0.62-0.67$ for $\left.\mathrm{MoV}\right)$. However, by calculating $\Delta=\left(\mathrm{V}^{4+}{ }_{\mathrm{R}}-\right.$ 
$\left.\mathrm{V}^{4+}{ }_{0}\right) / \mathrm{V}^{4+}{ }_{0}$, where $\mathrm{V}^{4+}{ }_{0}$ and $\mathrm{V}^{4+}{ }_{\mathrm{R}}$ relate to the initial and after reduction amounts respectively, it is seen that $\Delta=2.1-2.3$ for MoVNb vs. 1.3-1.5 for MoV. In other words, $\mathrm{Nb}$ favors the reduction of $\mathrm{V}$ which thus may enter the $\theta$-phase more easily, as shown by the presence of $\mathrm{Mo}_{1-\mathrm{x}} \mathrm{V}_{\mathrm{x}} \mathrm{O}_{2}$ in HT-XRD. By reoxidation at $300^{\circ} \mathrm{C}$, the initial mean valence state of $\mathrm{V}$ is not recovered. This may be due to the fact that Mo came onto the surface during reduction, the result being that some $\mathrm{V}$ specie are hidden and not reoxidized [46]. This trend is less marked in the presence of $\mathrm{Nb}$.

Previous work on the MoVNbO system by one of the authors [11] has demonstrated that the step of solubilization of ammonium metavanadate and of niobium oxide is prominent to avoid the presence of phases like $\mathrm{V}_{9} \mathrm{Mo}_{6} \mathrm{O}_{40}$, and that heat treatment in inert atmosphere ensures the formation of reduced Mo oxides. There are two ways for $\mathrm{MoO}_{3}$ to be partly reduced. The first one, which is common to $\mathrm{V}, \mathrm{Nb}, \mathrm{Ti}, \mathrm{W}$, oxides, is by means of crystallographic shear planes and gives rise to the socalled Magnéli phases. This mechanism has even been shown to proceed in the case of the reduction of $\alpha$ - or $\beta-\mathrm{VOPO}_{4}$ to $(\mathrm{VO})_{2} \mathrm{P}_{2} \mathrm{O}_{7}$, catalysts of mild oxidation of 1-butene or n-butane to maleic anhydride $[50,51]$. The second mechanism is responsible for the formation of pentagonal columns by extensive edge-sharing between polyhedra [45], and is common to $\mathrm{W}$, Te, etc., oxides as well as, e.g., uranium molybdates [52]. In the examined conditions [11], oxalic acid was leading to the formation of $\mathrm{Mo}_{18} \mathrm{O}_{52}$-type oxide, while hydrochloric acid favored the formation of $\theta-\mathrm{Mo}_{5} \mathrm{O}_{14}$. The stabilization by $\mathrm{V}$ and/or $\mathrm{Nb}$ was also assumed via their partial insertion in these phases. In the first case, the formation of acetic acid was concomitant to that of ethylene and observed at atmospheric pressure at as low as $200^{\circ} \mathrm{C}\left(\mathrm{S}_{\mathrm{AA}}=42, \mathrm{~S}_{\mathrm{C} 2}=45 \mathrm{~mol} \%\right)$, acetic acid decreasing while ethylene increased $\left(\mathrm{S}_{\mathrm{AA}}=2\right.$, $\mathrm{S}_{\mathrm{C} 2}=80 \mathrm{~mol} \%$ at $350^{\circ} \mathrm{C}$ ). In the second case, acetic acid was obtained at $200^{\circ} \mathrm{C}$ with very high selectivity (ca. $100 \mathrm{~mol} \%$ ) and then it decreased while ethylene increased $\left(\mathrm{S}_{\mathrm{AA}}=20, \mathrm{~S}_{\mathrm{C} 2}=55 \mathrm{~mol} \%\right.$ at $350^{\circ} \mathrm{C}$ ). In the present work, and although a detailed catalytic study has not yet been conducted, the behavior of all samples but MoV400 is similar: ethylene and acetic acid are obtained together, the former being in higher amounts, and only the conversion of ethane differs. In a short range of temperature $\left(40^{\circ} \mathrm{C}\right)$, the global selectivity amounts to $89-96 \mathrm{~mol} \%$. These findings must be related to the same system where $\theta-(\mathrm{VNbMo})_{5} \mathrm{O}_{14}$ and $\mathrm{MoO}_{3}$, are present, their crystalline state being mainly related to their catalytic activity. Werner et al. [30] have emphasized the role of the 'glassy nanocrystalline state' of such material in catalysis. On the contrary, if crystals of $\mathrm{MoO}_{3}$ are too large, and because they naturally exhibit mostly $\{010\}$ faces, the production of $\mathrm{CO}_{\mathrm{x}}$ is high [53]. This is the case of MoV400 catalyst which is characterized by the lowest surface area, ethylene conversion and selectivity to ethylene and acetic acid. Therefore, the conversion is as high as nanocrystallites are characterized by XRD and LRS, and selectivity is as high as the least amount of 'free' $\mathrm{MoO}_{3}$ is found on surface, that is for MoVNb350.

The relative role of these two phases is a different story which is related to synergistic effects $[54,55]$. Several examples of efficient catalysts containing 'free' $\mathrm{MoO}_{3}$ may be found in literature, and 
in most cases the latter is associated with cobalt molybdate, e.g., for maleic anhydride formation from n-butane [55, 56], or nickel molybdates for propane oxidative dehydrogenation [5759]. The model of $(\mathrm{Mo}, \mathrm{V}, \mathrm{Nb})_{5} \mathrm{O}_{14}$ microdomains in $\alpha-\mathrm{MoO}_{3}$ proposed in 1991 [11] (Fig. 8) and which emphasized the role of coherent interfaces, seems still topical.

\section{Conclusions}

The influence of niobium on the properties of $\mathrm{MoV}_{0.4}$-based catalysts is plural. Provided the preparation and the heat treatment of precursor is convenient so as to avoid the formation of $\mathrm{Mo}_{6} \mathrm{~V}_{9} \mathrm{O}_{40}$, Nb first allows the formation and the stabilization of $\theta-\mathrm{Mo}_{5} \mathrm{O}_{14}$ system. Niobium probably enters this lattice but also it seems to favor the incorporation of some vanadium (may be as $\mathrm{VMo}_{4} \mathrm{O}_{14}$ ), as indirectly shown by the formation of $\mathrm{Mo}_{1-\mathrm{x}} \mathrm{V}_{\mathrm{x}} \mathrm{O}_{2}$ during in situ XRD reduction of MoVNb samples. The disordering of the $\theta$ structure could result from the formation of $(\mathrm{VNbMo})_{5} \mathrm{O}_{14}$ solid solution. Second, during preparation and/or heat treatment, it favors the formation of $\mathrm{MoO}_{3}$ nanoparticles which, however, are more thermally stable as seen by laser heating (LRS) and less prone to move toward the surface (XPS). At this stage, it is difficult to say more about the possible presence of oxides structurally related to M1 or M2. Restricting ourselves to catalysts for ethane oxidation, these oxides are more easily observed in the absence of $\mathrm{Nb}$, e.g., $\mathrm{Mo}_{6} \mathrm{~V}_{2} \mathrm{M},(\mathrm{M}=\mathrm{Al}, \mathrm{Sb}, \mathrm{Te})$ provided they are hydrothermally prepared from Anderson heteropolymolybdates [19]. With our samples, the catalytic performance in strongly demanding conditions $\left(\mathrm{C}_{2} / \mathrm{O}_{2}=10\right)$, and particularly the high global selectivity (90-96 mol\%) as well as the ethylene-to-acetic acid ratio, is nearly the same every time both $\theta$ - $(\mathrm{VNbMo})_{5} \mathrm{O}_{14}$ and $\mathrm{MoO}_{3}$ oxides are characterized by XRD and LRS. Therefore, we suggest that synergistic effects between these structurally related oxides are responsible for the high values of selectivity, as well as for the modified reactivity of MoVNb in non catalytic conditions.

\section{Acknowledgements}

L. Burylo and L. Gengembre are thanked for performing HT-XRD and XPS experiments, respectively. M. Roussel and M. Bouchard are indebted to SABIC R\&D Management for financial support and approval to publish this work. 


\section{References}

[1] S. Albonetti, F. Cavani, F. Trifirò, Catal. Rev. Sci. Eng. 38 (1996) 414.

[2] F. Cavani, F. Trifirò, P. Arpentinier, The catalytic technology of oxidation, Technip, Paris, 2001.

[3] E. Bordes, Stud. Surf. Sci. Catal. 67 (1991) 21-30.

[4] E. Bordes, in "Elementary reaction steps in heterogeneous catalysis", R.W. Joyner and R.A. van Santen Eds, 1993, pp. 137-153, Kluwer Acad. Publ.

[5] A. Bielański, M. Najbar, Appl. Catal. A: General, 157 (1997) 223.

[6] V.M. Bondareva, T.V. Andrushkevich, E.A. Paukshtis, React. Kinet. Catal. Lett. 32 (1986) 71.

[7] J. Tichý, Appl. Catal. A: General, 157 (1997) 363.

[8] J.G. Eon, E. Bordes and P. Courtine, C.R. Acad. Sci. Paris, 288C (1979) 485-487.

[9] E. M. Thorsteinson, T.P, Wilson, F.G., Young, P.H., Kasai, J. Catal. 52 (1978) 116.

[10] R. Burch and R. Swarnakar, Appl. Catal. 70 (1991) 129.

[11] M. Merzouki, E. Bordes, B. Taouk, L. Monceaux, P. Courtine, Stud. Surf. Sci. Catal. 72 (1992) 81 .

[12] M. Merzouki, B. Taouk, L. Tessier, E. Bordes, P. Courtine, In "New Frontiers in Catalysis", L. Guczi, F. Solymosi, P. Tétényi, Eds., (1993) 753.

[13] K. Ruth, R. Kieffer and R. Burch, J. Catal. 175 (1998) 13; ibid., J. Catal. 175 (1998) 27.

[14] J.M. López Nieto, P. Botella, M.I. Vásquez, A. Dejoz, Chem. Commun. (2002) 1906.

[15] K. Karim, M. Al-Hazmi, E. Mamedov, US 5,907,056 (1999), to SABIC; K.Karim, M. AlHazmi, A. Khan, US 6,028,221 (2000), to SABIC.

[16] H. Borchert and U. Dingerdissen, Ger. Offen. DE 19630832 (1998), to Hoechst.

[17] M.D. Jones, S.J. Kitchen, J. Cook, B. Ellis, P. Howard, BP Chem., US 6,350,716 (2002).

[18] D. Linke, D. Wolf, M. Baerns, O. Timpe, R. Schlögl, S. Zeyß, U. Dingerdissen, J. Catal. 205 (2002) 16; D. Linke, D. Wolf, M. Baerns, S. Zeyß, U. Dingerdissen, J. Catal. 205 (2002) 32.

[19] W. Ueda and K. Oshihara, Appl. Catal. A: General, 200 (2000) 135.

[20] L. Tessier, E. Bordes, M. Gubelmann-Bonneau, Catal. Today 24 (1995) 335.

[21] M. Roy, M. Gubelmann-Bonneau, H. Ponceblanc, J.C. Volta, Catal. Lett. 42 (1996) 93.

[22] D.I. Enache, E. Bordes-Richard, A. Ensuque, F. Bozon-Verduraz, Appl. Catal., in press.

[23] E. Bordes, M. Gubelman, L. Tessier, French Patent 2720063 (1995), to Rhône-Poulenc Chimie; US Patent 6,114,274 (2000), to Rhône-Poulenc Chimie.

[24] G. Centi, S. Perathoner, F. Trifiró, Appl. Catal. A 157 (1997) 143.

[25] R. Catani, G. Centi, R. Grasselli, F. Trifiró, Ind. Eng. Chem., Res. 31 (1992) 107.

[26] A.T. Guttmann, R. K. Grasseli, J. F. Brazdil, US 4746641 (1998), to SOHIO

[27] H. Hibst, L. Marosi, A. Tenten, US 5,807,531 (1998), to BASF. 
[28] T. Ushikubo, H. Nakamura, US 5,380,933 (1995) to Mitsubishi.

[29] M. Lin, W.M. Linsen, EP 0962253 (1999) to Rohm\&Haas.

[30] H. Werner, O. Timpe, D. Herein, Y. Uchida, N. Pfänder, U. Wild, R. Schlögl, Catal. Lett. 44 (1997) 153.

[31] J.N. Al-Saedi, V.V. Giuliants, O. Guerrero-Pérez, M.A. Bañares, J. Catal., 215 (2003) 108.

[32] H. Vogel, R. Böhling and H. Hibst, Catal. Lett. 62 (1999) 71.

[33] K. Karim, Y.S. Bhat, S. Zaheer, A. Nafisah, US Patent 6,143,928 (2000); US Patent 6,114,278 (2000), to SABIC.

[34] M. Dieterle, G. Mestl, J. Jäger, Y. Uchida, H. Hibst, R. Schlögl, J. Molec. Catal. A: Chemical, 174 (2001) 169.

[35] G. Mestl, J. Raman Spectrosc. 33 (2002) 333.

[36] M. Aouine, J.L. Dubois, J.M.M. Millet, Chem. Commun. (2001) 1180.

[37] D. Vitry, J.L. Dubois, Y. Morikawa, W. Ueda, TOCAT 2002, p.141.

[38] J.M.M. Millet, H. Roussel, A. Pigamo, J.L. Dubois, J.C. Dumas, Appl. Catal. A: General, 232 (2003) 77.

[39] P. De Santo Jr., D.J. Buttrey, R.K. Grasselli, C.G. Lugmair, A.F. Volpe, B.H. Toby, T. Vogt, Topics Catal. 23 (2003) 23.

[40] R. K. Grasselli, J.D. Burrington, D.J. Buttrey, P. De Santo Jr., C.G. Lugmair, A.F. Volpe, T. Weingnd, Topics Catal. 23 (2003) 5.

[41] P. De Santo Jr., D.J. Buttrey, R.K. Grasselli, C.G. Lugmair, A.F. Volpe, B.H. Toby, T. Vogt,, Z. Krist. 219 (2004) 152.

[42] E. Garcia-Gonzales, J.M. López-Nieto, P. Botella, J.M. Gonzáles-Calbet., Chem. Mater. 14 (2002) 4416.

[43] P. Moriceau, A. Lebouteiller, E. Bordes and P. Courtine, Phys. Chem. Chem. Phys. 1 (1999) 5735-5744; P. Moriceau, B. Taouk, E. Bordes, P. Courtine, Catal. Today 61 (2000) 197-201; ibid., Stud. Surf. Sci. Catal. 130 (2000) 1811.

[44] E. Bordes-Richard, P. Courtine, In "Metal Oxides: Chemistry and Applications", J.L.J. Fierro Ed., Marcel Dekker, 2004, submitted.

[45] T. Eckström and M. Nygren, Acta Chem. Scand. 26 (1972) 1827; ibid., 1836.

[46] G. Mestl, Ch. Linsmeier, R. Gottschall, M. Dieterle, J. Find, D. Herein, J. Jäger, Y. Uchida, R. Schlögl, J. Molec. Catal. A: Chemical, 162 (2000) 463.

[47] F. Barbieri, D. Cauzz, F. De-Smet, M. Devillers, P. Moggi, Catal. Today 61 (2000) 353.

[48] S.A. Holmes, J. Al-Saeedi, V.V. Guliants, P. Boolchand, D. Georgiev, U. Hackler, E. Sobkow, Catal. Today, 67 (2001) 403.

[49] R.D. Shannon, Acta Crystallogr. Sect. A, 32 (1976) 751.

[50] E. Bordes and P. Courtine, J. Catal. 57 (1979) 237. 
[51] E. Bordes, Catal. Today, 1 (1987) 499; ibid., 3 (1987) 163.

[52] S.J. Jung, E. Bordes et P. Courtine, Proc. IXth Ibero-American Symp. on Catalysis, 2 (1984) 983.

[53] J.C. Volta and J.M. Tatibouet, J. Catal. 93 (1985) 467.

[54] P. Courtine, E. Bordes, Appl. Catal. A: General 157 (1997) 45.

[55] E. Bordes, Topics Catal. 15 (2001) 131.

[56] J.S. Jung, E. Bordes, P. Courtine, Stud. Surf. Sci. Catal. 21 (1985) 345.

[57] U. Ozkan and G.L. Schrader, J. Catal., 95 (1985) 120.

[58] O. Lezla, E. Bordes, P. Courtine and G. Hecquet, J. Catal. 170 (1997) 346.

[59] D.L. Stern and R.K. Grasselli, J. Catal. 167 (1997) 550. 


\section{$\underline{\text { Table captions }}$}

Table 1. Surface atomic ratios determined by XPS and stoichiometry of MoV and MoVNb catalysts.

Table 2. Reduction of MoV and MoVNb catalysts by hydrogen and reoxidation by air, followed by XPS.

Table 3. Reduction of MoV and MoVNb catalysts by propane and by ethane, and reoxidation by air, followed by XPS.

Table 4. Surface area and catalytic performance of MoV and MoVNb catalysts in the oxidation of ethane to ethylene and acetic acid.

Table 5. Main Mo- and MoV-based oxides (Mo/V > 1:1). exhibiting (or not) a line ca. $d=4 \AA$ in their XRD pattern. 
Table 1. Surface atomic ratios determined by XPS and stoichiometry of MoV and MoVNb catalysts.

\begin{tabular}{c|c|c|c|c|c}
\hline Catalyst & $\mathbf{V} / \mathbf{M o}$ & $\mathbf{N b} / \mathbf{M o}$ & $\mathbf{V}^{4+} / \mathbf{V t o t}$ & $\mathbf{V}^{4+} / \mathbf{M o}$ & Surface Stoichiometry \\
\hline MoV350* & 0.26 & - & 0.269 & 1.0 & $\mathrm{Mo}^{6+} \mathrm{V}^{5+}{ }_{0.19} \mathrm{~V}^{4+}{ }_{0.07} \mathrm{O}_{3.615}$ \\
\hline MoV400* & 0.50 & - & 0.260 & 0.5 & $\mathrm{Mo}^{6+} \mathrm{V}^{5+}{ }_{0.37} \mathrm{~V}^{4+}{ }_{0.13} \mathrm{O}_{4.185}$ \\
\hline MoVNb350 & 0.31 & 0.11 & 0.194 & 0.6 & $\mathrm{Mo}^{6+} \mathrm{V}^{5+}{ }_{0.25} \mathrm{~V}^{4+}{ }_{0.06} \mathrm{Nb}_{0.11} \mathrm{O}_{4.02}$ \\
\hline MoVNb400
\end{tabular}


Table 2. Reduction of MoV and MoVNb catalysts by hydrogen and reoxidation by air, followed by XPS.

\begin{tabular}{|c|c|c|c|c|c|}
\hline MoV350 & $\mathbf{V} / \mathbf{M o}$ & $\mathbf{N b} / \mathbf{M o}$ & $\mathbf{V}^{4+} / \mathbf{V}_{\text {tot }}$ & $\mathbf{V}^{4+} / \mathbf{M o}$ & Surface Stoichiometry \\
\hline Before reduction & 0.26 & - & 0.269 & 1.0 & $\mathrm{Mo}^{6+} \mathrm{V}^{5+}{ }_{0.19} \mathrm{~V}^{4+}{ }_{0.07} \mathrm{O}_{3.615}$ \\
\hline Reduction & 0.26 & - & 0.654 & 2.5 & $\mathrm{Mo}^{6+} \mathrm{V}^{5+}{ }_{0.09} \mathrm{~V}^{4+}{ }_{0.17} \mathrm{O}_{3.565}$ \\
\hline Reoxidation & 0.26 & - & 0.385 & 1.5 & $\mathrm{Mo}^{6+} \mathrm{V}^{5+}{ }_{0.16} \mathrm{~V}^{4+}{ }_{0.10} \mathrm{O}_{3.60}$ \\
\hline MoVNb350 & & & & & \\
\hline Before reduction & 0.31 & 0.11 & 0.194 & 0.6 & $\mathrm{Mo}^{6+} \mathrm{V}^{5+}{ }_{0.25} \mathrm{~V}^{4+}{ }_{0.06} \mathrm{Nb}^{5+}{ }_{0.11} \mathrm{O}_{4.02}$ \\
\hline Reduction & 0.28 & 0.14 & 0.643 & 2.3 & $\mathrm{Mo}^{6+} \mathrm{V}^{5+}{ }_{0.10} \mathrm{~V}^{4+}{ }_{0.18} \mathrm{Nb}^{5+}{ }_{0.14} \mathrm{O}_{3.96}$ \\
\hline Reoxidation & 0.33 & 0.16 & 0.273 & 0.8 & $\mathrm{Mo}^{6+} \mathrm{V}^{5+}{ }_{0.24} \mathrm{~V}^{4+}{ }_{0.09} \mathrm{Nb}^{5+}{ }_{0.16} \mathrm{O}_{4.18}$ \\
\hline
\end{tabular}


Table 3. Reduction of MoV and MoVNb catalysts by propane and by ethane, and reoxidation by air, followed by XPS.

\begin{tabular}{|c|c|c|c|c|c|c|c|c|}
\cline { 2 - 10 } \multicolumn{1}{c|}{} & \multicolumn{4}{c|}{ Propane } & \multicolumn{4}{c|}{ Ethane } \\
\hline MoV350 & V/Mo & $\mathbf{N b} / \mathbf{M o}$ & $\mathbf{V}^{4+} / \mathbf{V}_{\text {tot }}$ & $\mathbf{V}^{4+} / \mathbf{M o}$ & $\mathbf{V} / \mathbf{M o}$ & $\mathbf{N b} / \mathbf{M o}$ & $\mathbf{V}^{4+} / \mathbf{V}_{\text {tot }}$ & $\mathbf{V}^{4+} / \mathbf{M o}$ \\
\hline Before reduction & 0.26 & - & 0.269 & 1.0 & 0.26 & - & 0.269 & 1.0 \\
\hline Reduction & 0.26 & - & 0.615 & 2.4 & 0.27 & - & 0.673 & 2.5 \\
\hline Reoxidation & 0.26 & - & 0.423 & 1.6 & 0.28 & - & 0.357 & 1.3 \\
\hline MoVNb350 & & & & & & & & \\
\hline Before reduction & 0.31 & 0.11 & 0.194 & 0.6 & 0.31 & 0.11 & 0.194 & 0.6 \\
\hline Reduction & 0.27 & 0.13 & 0.593 & 2.2 & 0.33 & 0.09 & 0.607 & 1.8 \\
\hline Reoxidation & 0.29 & 0.12 & 0.414 & 1.4 & 0.34 & 0.09 & 0.295 & 0.9 \\
\hline
\end{tabular}


Table 4. Surface area and catalytic performance ( $\mathrm{mol} \%$ ) of $\mathrm{MoV}$ and $\mathrm{MoVNb}$ catalysts in the oxidation of ethane to ethylene and acetic acid.

\begin{tabular}{|c|c|c|c|c|c|c|c|c|c|}
\hline & $\begin{array}{c}\mathrm{S}_{\mathrm{BET}} \\
\left(\mathbf{m}^{2} \mathbf{g}^{-1}\right)\end{array}$ & $\begin{array}{l}\text { Temp. } \\
\left({ }^{\circ} \mathrm{C}\right)\end{array}$ & $\begin{array}{l}\text { Conv. } \\
\mathrm{C}_{2} \mathrm{H}_{6}\end{array}$ & $\begin{array}{c}\text { Conv. } \\
\mathrm{O}_{2}\end{array}$ & $\begin{array}{l}\text { Sel. } \\
\text { AA }\end{array}$ & $\begin{array}{l}\text { Sel. } \\
\mathrm{C}_{2} \mathbf{H}_{4}\end{array}$ & $\begin{array}{c}\text { Sel. } \\
\mathrm{AA}+\mathrm{C}_{2}\end{array}$ & $\begin{array}{l}\text { Sel. } \\
\text { CO }\end{array}$ & $\begin{array}{l}\text { Sel. } \\
\mathrm{CO}_{2}\end{array}$ \\
\hline \multirow{3}{*}{$\begin{array}{c}\mathrm{Mo}_{1} \mathrm{~V}_{0.398}{ }^{*} \\
\text { MoV350 }\end{array}$} & \multirow{3}{*}{34} & 240 & 3.5 & 26.0 & 27.0 & 66.0 & 93.0 & 3.0 & 4.0 \\
\hline & & 260 & 8.0 & 55.1 & 29.0 & 61.0 & 90.0 & 5.0 & 5.0 \\
\hline & & 280 & 11.0 & 77.4 & 30.0 & 57.0 & 87.0 & 6.0 & 7.0 \\
\hline \multirow{3}{*}{$\begin{array}{c}\mathrm{Mo}_{1} \mathrm{~V}_{0.398}{ }^{*} \\
\text { MoV400 }\end{array}$} & \multirow{3}{*}{21} & 240 & 1.5 & 11.2 & 19.0 & 53.0 & 72.0 & 12.0 & 16.0 \\
\hline & & 260 & 2.0 & 19.4 & 17.0 & 46.0 & 63.0 & 14.5 & 23.0 \\
\hline & & 280 & 2.5 & 33.8 & 16.0 & 34.0 & 50.0 & 21.0 & 29.0 \\
\hline \multirow{3}{*}{$\begin{array}{c}\mathrm{Mo}_{1} \mathrm{~V}_{0.398} \mathrm{Nb}_{0.125} * \\
\text { MoVNb350 }\end{array}$} & \multirow{3}{*}{26} & 240 & 6.5 & 33.5 & 27.0 & 69.0 & 96.0 & 1.5 & 2.3 \\
\hline & & 260 & 11.0 & 62.9 & 29.0 & 66.0 & 95.0 & 2.3 & 3.0 \\
\hline & & 280 & 13.5 & 88.2 & 31.0 & 62.0 & 93.0 & 3.0 & 4.0 \\
\hline \multirow{3}{*}{$\begin{array}{c}\mathrm{Mo}_{1} \mathrm{~V}_{0.398} \mathrm{Nb}_{0.125} \text { * } \\
\text { MoVNb400 }\end{array}$} & \multirow{3}{*}{24} & 240 & 6.0 & 33.4 & 27.0 & 69.0 & 96.0 & 2.0 & 2.0 \\
\hline & & 260 & 9.5 & 63.5 & 26.0 & 66.0 & 92.0 & 4.0 & 4.0 \\
\hline & & 280 & 12.0 & 92.9 & 25.0 & 65.0 & 90.0 & 5.0 & 5.0 \\
\hline
\end{tabular}

* Sample composition; AA: Acetic Acid, $\mathrm{C}_{2}: \mathrm{C}_{2} \mathrm{H}_{4}$ 
Table 5. Main Mo- and MoV-based oxides (Mo/V > 1:1) exhibiting (or not) a line ca. $d=4 \AA$ in their XRD pattern.

\begin{tabular}{|c|c|c|c|c|c|}
\hline Phase & Mo/V & $\begin{array}{c}\text { Crystal } \\
\text { structure }\end{array}$ & Parameters & $\mathrm{JCPDS}^{\circ}$ & $\begin{array}{l}\text { Line at } \\
\text { ca. } 4 \AA\end{array}$ \\
\hline $\mathrm{V}_{0.95} \mathrm{Mo}_{0.97} \mathrm{O}_{5}$ & 1.02 & triclinic & $\begin{array}{ll}\mathrm{a}=6.334 \AA & \alpha=90.00^{\circ} \\
\mathrm{b}=4.046 \AA & \beta=7.30^{\circ} \\
\mathrm{c}=3.725 \AA & \gamma=90.50^{\circ} \\
\end{array}$ & 77-0649 & yes \\
\hline $\mathrm{VMo}_{3} \mathrm{O}_{11}$ & 3.0 & hexagonal & $\begin{array}{c}\mathrm{a}=\mathrm{b}=4.00 \AA \\
\mathrm{c}=3.76 \AA \quad \beta=120^{\circ}\end{array}$ & {$[6,7]$} & yes \\
\hline $\mathrm{V}_{0.13} \mathrm{Mo}_{0.87} \mathrm{O}_{2.935}$ & 6.70 & hexagonal & $\begin{array}{c}\mathrm{a}=\mathrm{b}=10.592 \AA \\
\mathrm{c}=3.699 \AA \quad \AA \quad \beta=120^{\circ}\end{array}$ & $48-0766$ & no \\
\hline $\mathrm{V}_{0.12} \mathrm{Mo}_{0.88} \mathrm{O}_{2.94}$ & 7.33 & hexagonal & $\begin{array}{c}\mathrm{a}=\mathrm{b}=10.593 \AA \\
\mathrm{c}=3.694 \AA \quad \beta=120^{\circ}\end{array}$ & $81-2414$ & no \\
\hline $\begin{array}{c}\mathrm{V}_{\mathrm{x}} \mathrm{Mo}_{1-\mathrm{x}} \mathrm{O}_{2.80} \\
0 \leq \mathrm{x} \leq 1.0\end{array}$ & 0 to 15 & $\begin{array}{c}\text { tetragonal } \\
\left(\mathrm{Mo}_{5} \mathrm{O}_{14} \text {-type }\right)\end{array}$ & variable & $31-1437$ & yes \\
\hline h- $-\mathrm{MoO}_{3}$ & - & hexagonal & $\begin{array}{c}\mathrm{a}=\mathrm{b}=10.531 \AA \\
\mathrm{c}=14.876 \AA \quad \beta=120^{\circ}\end{array}$ & $21-0569$ & no \\
\hline $\mathrm{Mo}_{4} \mathrm{O}_{11}$ & - & orthorhombic & $\begin{array}{c}a=24.54 \AA \quad b=5.457 \AA \\
c=6.752 \AA\end{array}$ & $84-0687$ & yes \\
\hline
\end{tabular}




\section{Figure captions:}

Fig. 1: XRD patterns of $\mathrm{MoV}_{0.4} \mathrm{O}_{\mathrm{x}}(\mathrm{MoV})$ and $\mathrm{MoV}_{0.4} \mathrm{Nb}_{0.12} \mathrm{O}_{\mathrm{y}}(\mathrm{MoVNb})$ catalysts calcined at $\mathrm{Tc}=350$ or $400^{\circ} \mathrm{C}-\left(\bullet \alpha-\mathrm{MoO}_{3}\right)$.

Fig. 2: Raman spectra of $\mathrm{MoV}_{0.4} \mathrm{O}_{\mathrm{x}}(\mathrm{MoV})$ and $\mathrm{MoV}_{0.4} \mathrm{Nb}_{0.12} \mathrm{O}_{\mathrm{y}}(\mathrm{MoVNb})$ catalysts calcined at $\mathrm{Tc}=350$ or $400^{\circ} \mathrm{C}$.

Fig. 3: XRD patterns of in situ reduction of MoV350 in $\mathrm{H}_{2} / \mathrm{N}_{2}$ atmosphere at various temperatures $\left(\propto \mathrm{MoO}_{2}\right)$.

Fig. 4: XRD patterns of in situ reoxidation of the formerly reduced $\mathrm{MoV} 350$ at $450^{\circ} \mathrm{C}$ and back to R.T. ( $\left.\circ \alpha-\mathrm{MoO}_{3}, * \mathrm{~V}_{2} \mathrm{MoO}_{8} / \mathrm{Mo}_{6} \mathrm{~V}_{9} \mathrm{O}_{40}\right)$.

Fig. 5: XRD patterns of reduction of MoVNb350 in $\mathrm{H}_{2} / \mathrm{N}_{2}$ atmosphere at various temperatures.

Fig. 6: XRD pattern of reoxidation of the formerly reduced $\mathrm{MoVNb} 350\left(\circ \alpha-\mathrm{MoO}_{3}\right.$, * $\left.\mathrm{V}_{2} \mathrm{MoO}_{8} / \mathrm{Mo}_{6} \mathrm{~V}_{9} \mathrm{O}_{40}\right)$.

Fig. 7: XPS analysis of MoVNb350 after pretreatments; Binding Energy of Mo, V, Nb - (a) before reduction, (b) after reduction in $\mathrm{H}_{2} / \mathrm{N}_{2}$ and (c) after reoxidation in $\mathrm{O}_{2} / \mathrm{N}_{2}$.

Fig. 8: Model of coherent interfaces between $\theta-(\mathrm{VNbMo})_{5} \mathrm{O}_{14}$ and $\alpha-\mathrm{MoO}_{3}$; after [11]. 


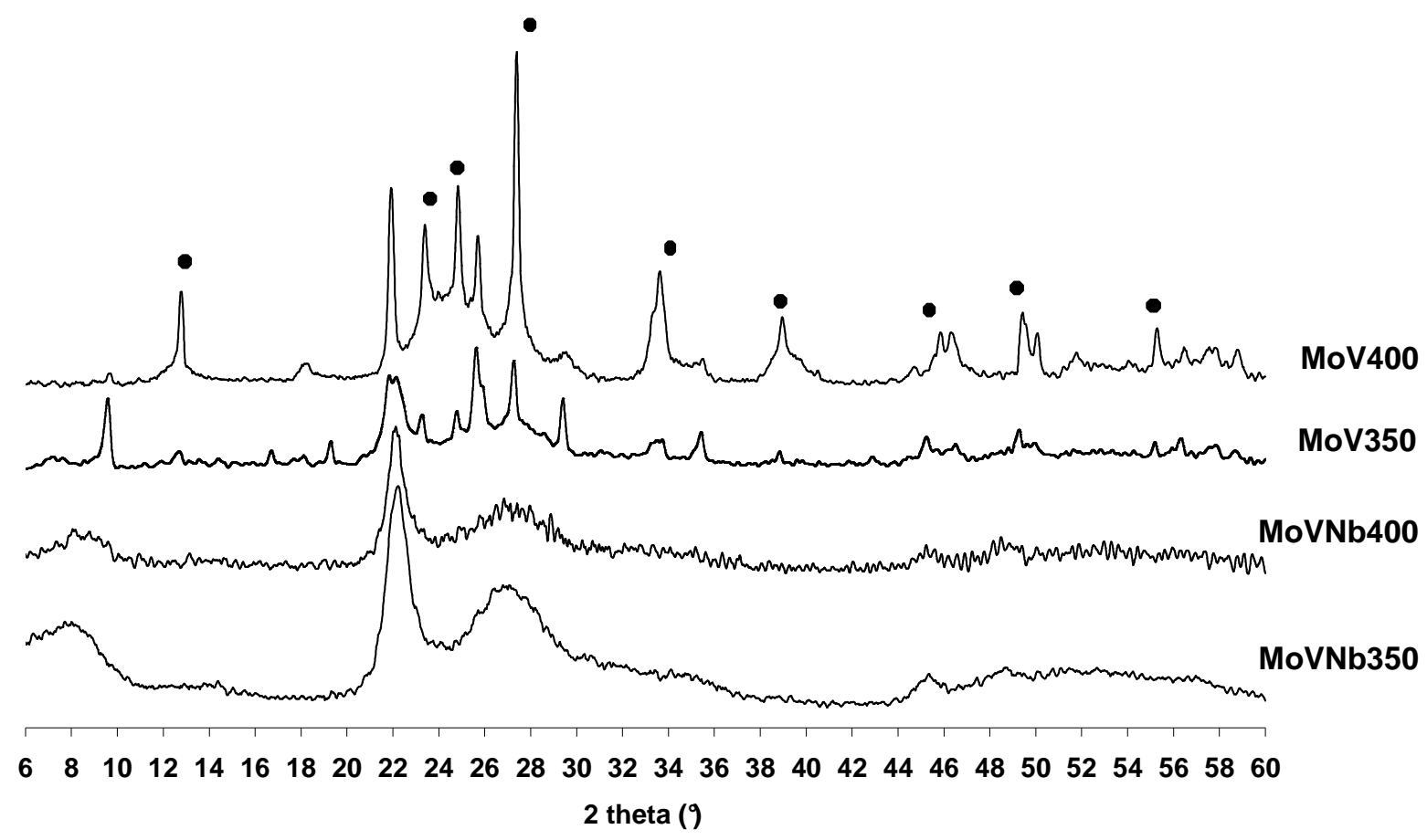

Fig. 1: XRD patterns of $\mathrm{MoV}_{0.4} \mathrm{O}_{\mathrm{x}}(\mathrm{MoV})$ and $\mathrm{MoV}_{0.4} \mathrm{Nb}_{0.12} \mathrm{O}_{\mathrm{y}}(\mathrm{MoVNb})$ catalysts calcined at $\mathrm{Tc}=350$ or $400^{\circ} \mathrm{C}-\left(\bullet \alpha-\mathrm{MoO}_{3}\right)$. 


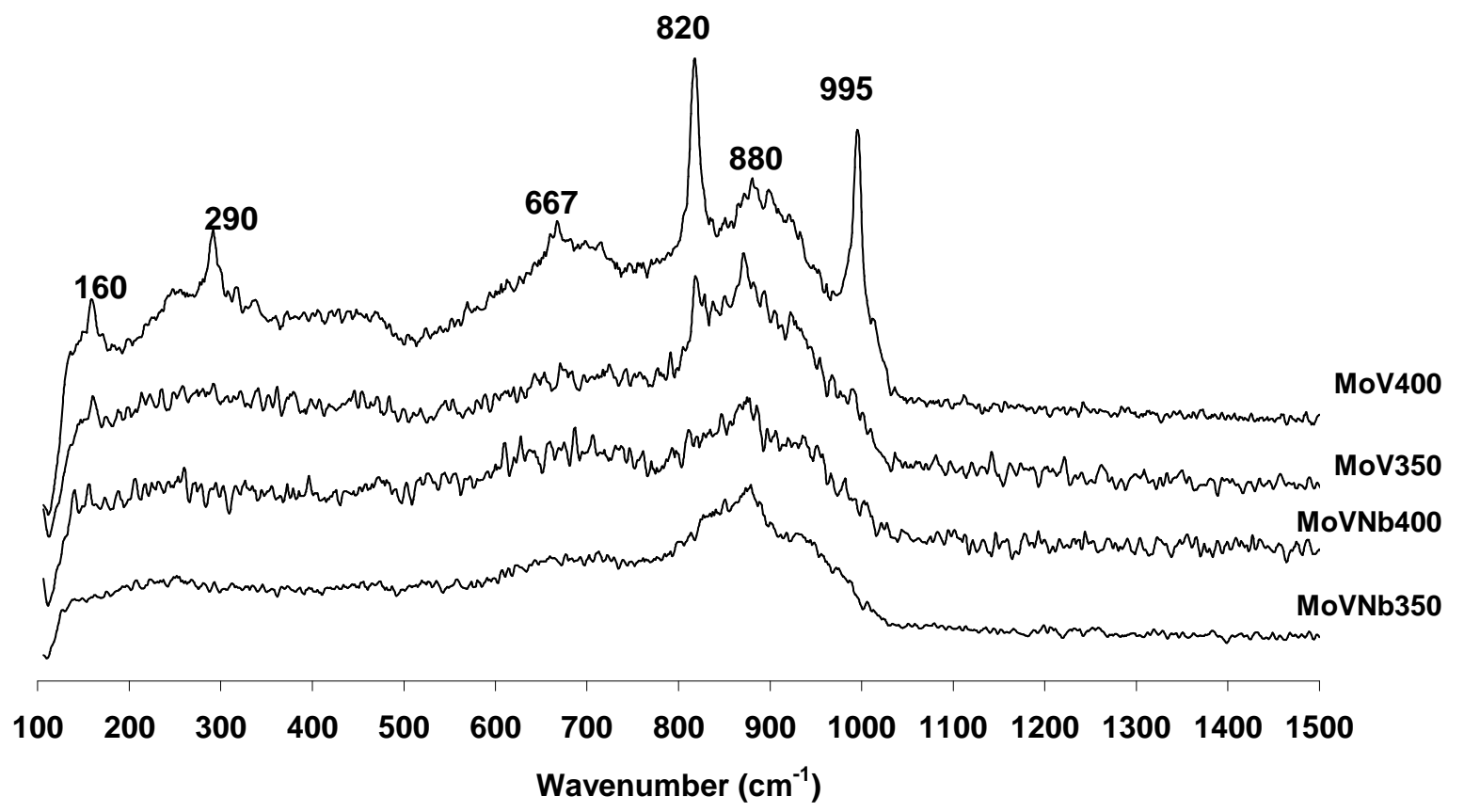

Fig. 2: Raman spectra of $\mathrm{MoV}_{0.4} \mathrm{O}_{\mathrm{x}}(\mathrm{MoV})$ and $\mathrm{MoV}_{0.4} \mathrm{Nb}_{0.12} \mathrm{O}_{\mathrm{y}}$ (MoVNb) catalysts calcined at $\mathrm{Tc}=350$ or $400^{\circ} \mathrm{C}$. 


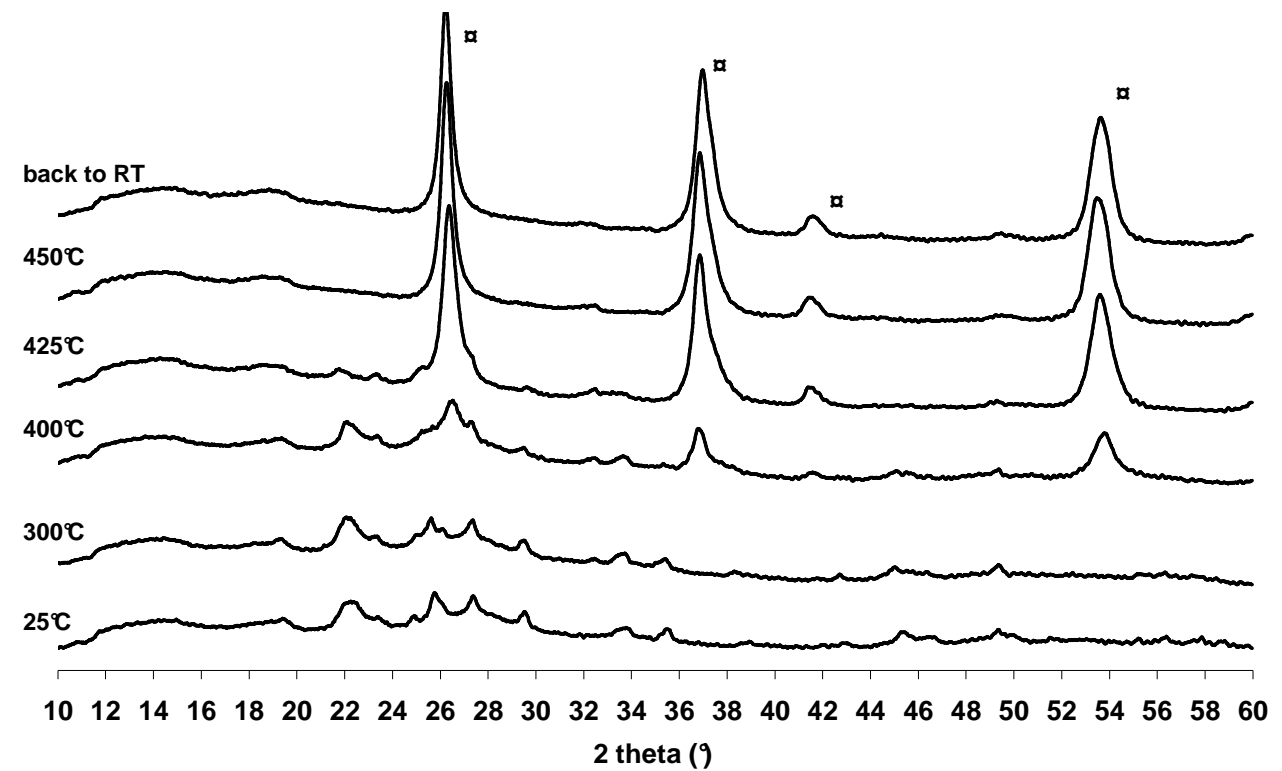

Fig. 3: XRD patterns of in situ reduction of MoV350 in $\mathrm{H}_{2} / \mathbf{N}_{2}$ atmosphere at various temperatures $\left(\ltimes \mathrm{MoO}_{2}\right)$. 


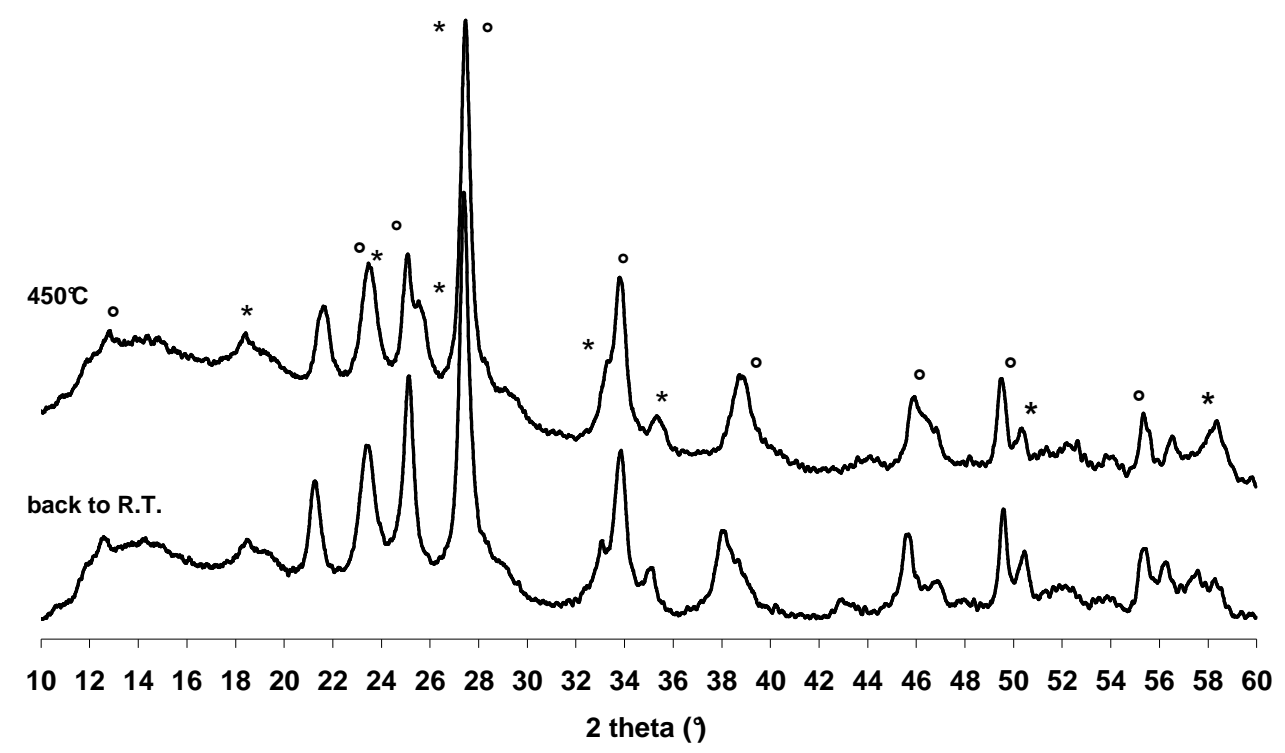

Fig. 4: XRD patterns of in situ reoxidation of the formerly reduced $\mathrm{MoV350}$ at $450^{\circ} \mathrm{C}$ and back to R.T. $\left({ }^{\circ} \alpha-\mathrm{MoO}_{3}, * \mathrm{~V}_{2} \mathrm{MoO}_{8} / \mathrm{Mo}_{6} \mathrm{~V}_{9} \mathrm{O}_{40}\right)$. 


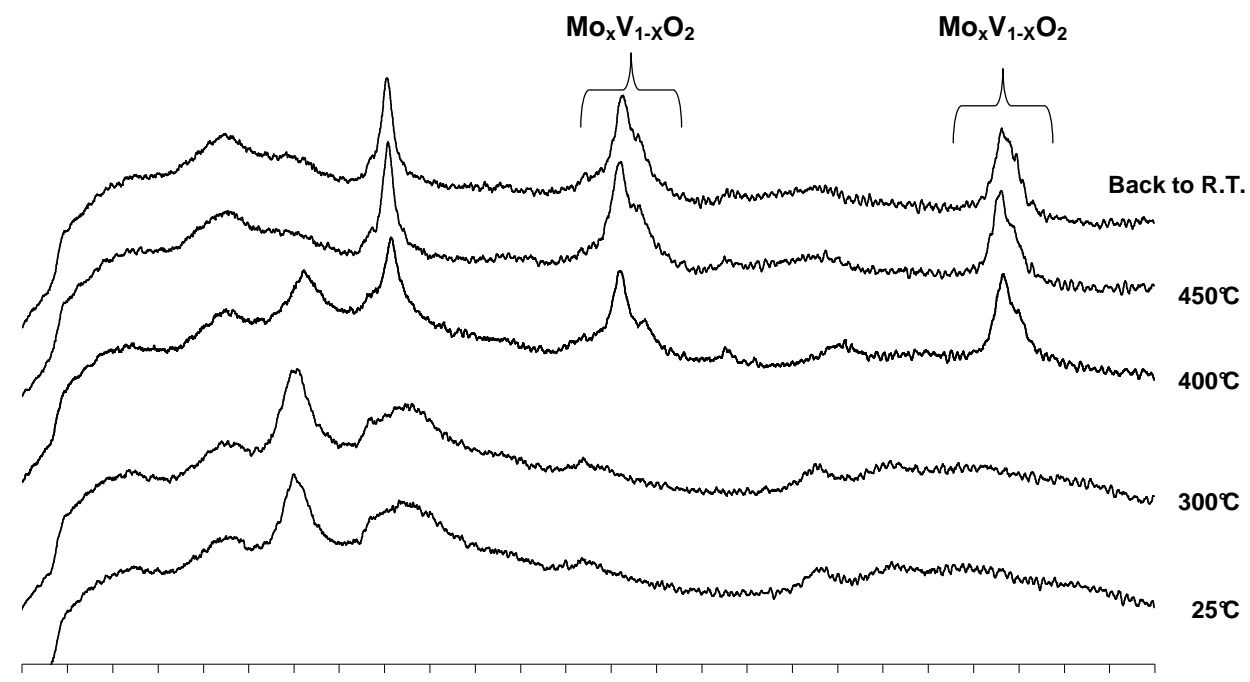

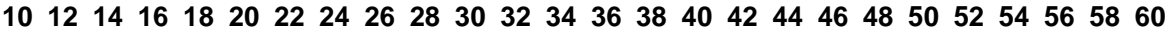
2 Theta $(9$

Fig. 5: XRD patterns of reduction of $\mathrm{MoVNb350}$ in $\mathrm{H}_{2} / \mathrm{N}_{2}$ atmosphere at various temperatures. 


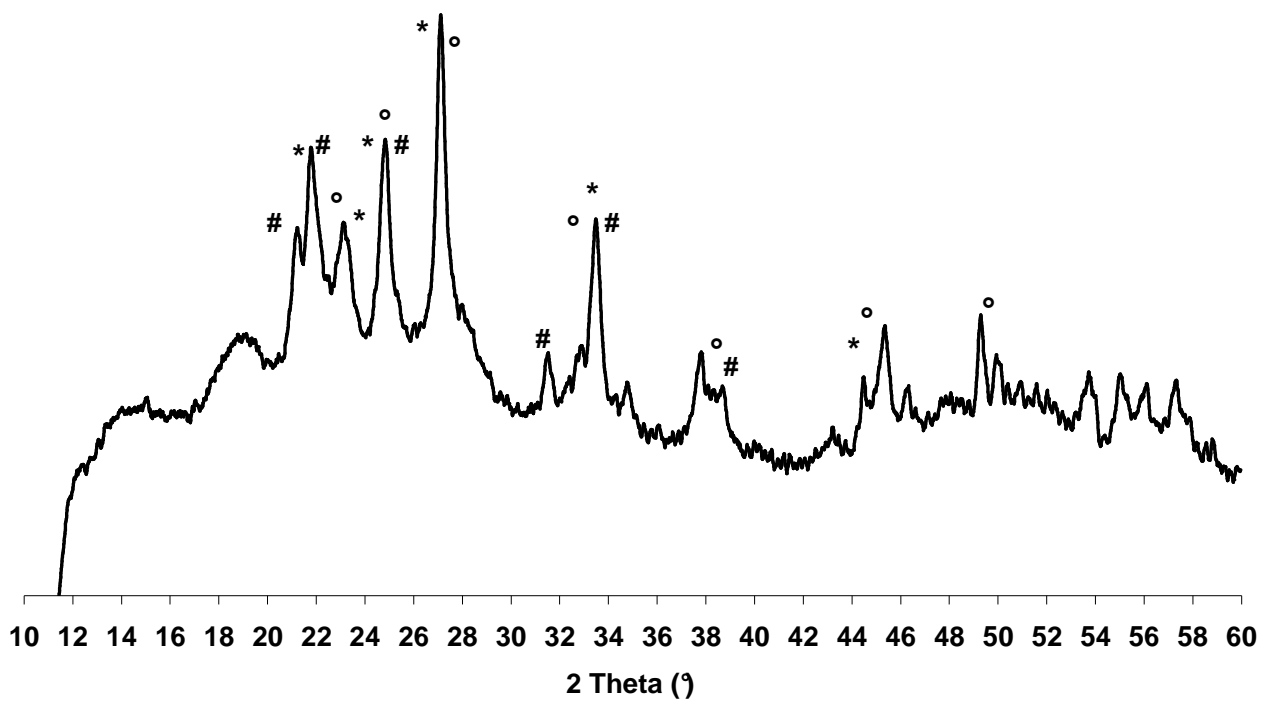

Fig. 6: XRD pattern of reoxidation of the formerly reduced $\mathrm{MoVNb350}\left(\circ \alpha-\mathrm{MoO}_{3}\right.$, * $\left.\mathrm{V}_{2} \mathrm{MoO}_{8} / \mathrm{Mo}_{6} \mathrm{~V}_{9} \mathrm{O}_{40},{ }^{\#}(\mathrm{VNbMo})_{5} \mathrm{O}_{14}\right)$. 


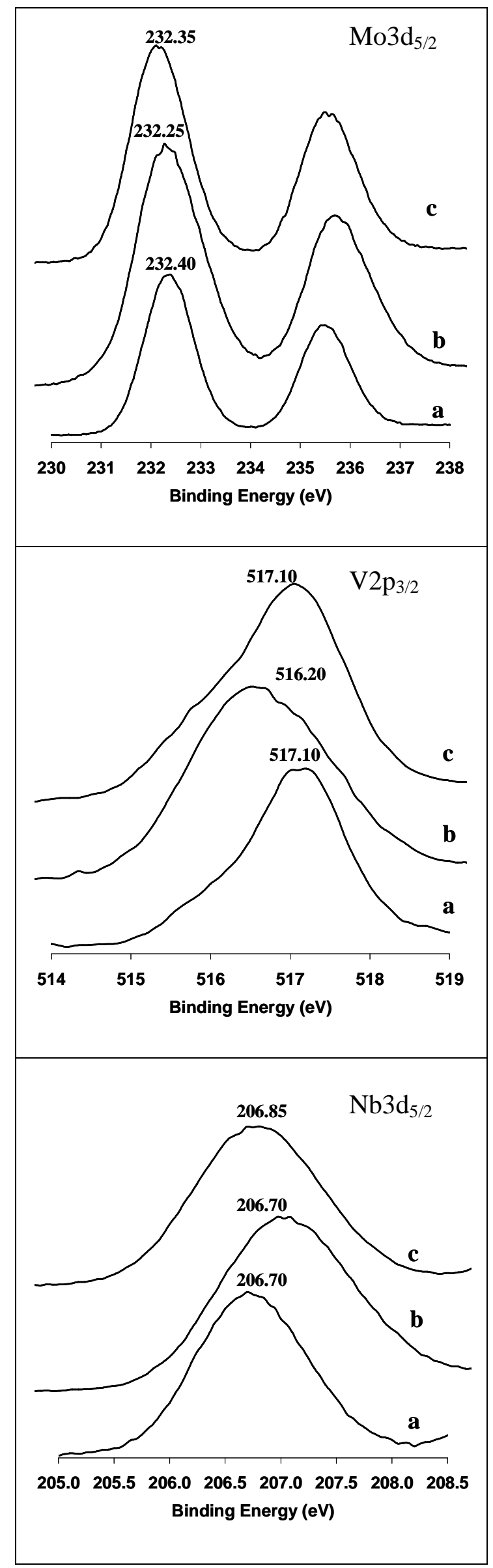

Fig. 7: XPS analysis of MoVNb350 after pretreatments; Binding Energy of Mo, V, Nb - (a) before reduction, (b) after reduction in $\mathrm{H}_{2} / \mathrm{N}_{2}$ and (c) after reoxidation in $\mathrm{O}_{2} / \mathbf{N}_{2}$. 


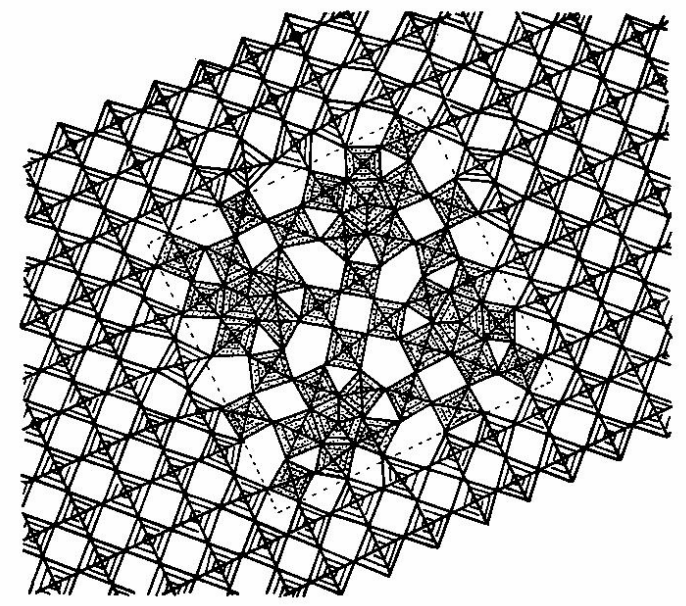

Fig. 8: Model of coherent interfaces between $\theta-(\mathrm{VNbMo})_{5} \mathrm{O}_{14}$ and $\alpha-\mathrm{MoO}_{3}$; after [11]. 
